\title{
Scaring Birds: The concept of the Scarecrow in Ancient Egypt
}

Walaa Mohamed Abdelhakim*

Faculty of Tourism and Hotels, Minia University, Egypt

\section{ARTICLE INFO}

Keywords:

Scarecrow

Scarer

Birds

Corn Dolly

Field

\begin{abstract}
Throughout history scarecrows were made and used by various cultures round the world. Generally, the scarecrow is the straw object set up in the fields and gardens to scare birds away from the crops are growing. In ancient Egypt various methods were used with the same concept as the scarecrow to protect the harvest from birds' attacks. The research displays and discusses these methods that appeared throughout the different periods of the ancient Egyptian history. To achieve the aim of the study the descriptive and analytical methodology will be employed. In spite of the lack of references that clearly and directly deal with the ancient Egyptian scarecrow the study resulted in certain important points including the three main methods that were used to scare birds as scarecrow in fields and gardens and were represented in the ancient Egyptian harvest scenes: bird netting (the ground net), scarer, and corn dolly.

(C)2020 Faculty of Tourism and Hotels, Fayoum University All rights reserved
\end{abstract}

\section{Introduction}

The scarecrow is considered to be the output of a culture tightly linked with agriculture. Ever since people devoted themselves to land agriculture, birds have been the greatest threat to sowing and harvesting. The harm caused by birds on crops in the years of harvest failure could even lead a family to starvation in the winter. To ward off this harm, family members used to protect and guard their fields, and farmers started to invent and design scarecrows to deter birds (Król, Kao, and Hernik, 2019).

Scarecrow is an English word meaning a man employed as a "Scarer" to scare away crows from fields. He might chase the crows while screaming, rattling or shaking clappers, or waving sticks (Sax, 2003).

The image of a man of straw was not the earliest form of the scarecrow in ancient Egypt, but methods and objects aimed at deterring everything that could cause a threat to the crops. Several methods for scaring birds away were used in ancient Egypt. They were found in gardens, orchards, and cultivated fields (Król, Kao, and Hernik, 2019).

\section{The objectives of the study}

This study deals with the protection measures and methods used with the same concept of scarecrows for scaring birds in the ancient Egyptian fields and gardens. The paper main objectives include the followings:

- Clarifying the agricultural stages in which the concept of scarecrow is attested.

- Determining the main methods used for scaring birds in the ancient Egyptian fields, orchards, and gardens.

- Establishing the earliest form of scarecrow in the ancient Egyptian field and garden.

\footnotetext{
* Contact Walaa Mohamed Abdelhakim at: walaa.abdelhakeem@mu.edu.eg
} 


\section{Methodology}

The suitable methodology that will be employed to achieve the aim of the study is the descriptive and analytical one for what was collected from scenes and data concerning the main subject of the research.

\section{Discussion and Results}

4.1Protection measures and methods used like the scarecrows for scaring birds in fields and gardens

\subsubsection{The Ground Net in Fields}

Along the Nile River, the earliest method in recorded history to safeguard corn fields from the bevy of quails (Coturnix coturnix) that used to stop to feed in the fields of wheat during their spring journey toward the north. The ancient Egyptian farmers used to design wooden frames covered in netting and place them in the fields of corn. They then tied long cords of white fabric to their bodies and hid to surprise and catch the unsuspecting bird, thus saving their crops and also having birds to eat (Wassell, 1991; Kimball, 2016; Bailleul-LeSuer, 2016).

Fig. 1
This might be supported from the scenes representing wooden frames covered in netting employed for catching quails in the fields. The latter was known as "the ground or hand net" (Slingenberg, 2016). It appeared in the harvest scenes of the Old Kingdom tomb of Mereruka at Saqqara and on a fragment from the New Kingdom private tomb of Nebamun at Thebes (Bailleul-lesuer, 2012). The scenes express the birds' shock that most of them fell into the previously well prepared nets and got tightly trapped.

The scene of Mereruka (Fig. 1) shows four farmers involved in the netting of a bevy of quails in a grain field. It is the harvest season, and the crop is being gathered. The trapping occurs in a part of the field that the harvesters have already reaped except for the long stubble of the stalks that remains. The four farmers appear in two pairs on each side of the net. Each one holds a rope that is tightly tied to a corner of the net. The birds were depicted in the instant of their rush upward (Houlihan, 1986; Kanawati, 2007). Thus, the netting here is meant to protect the harvest from birds through catching them.

The ground net in the Old Kingdom tomb of Mereruka at Saqqara

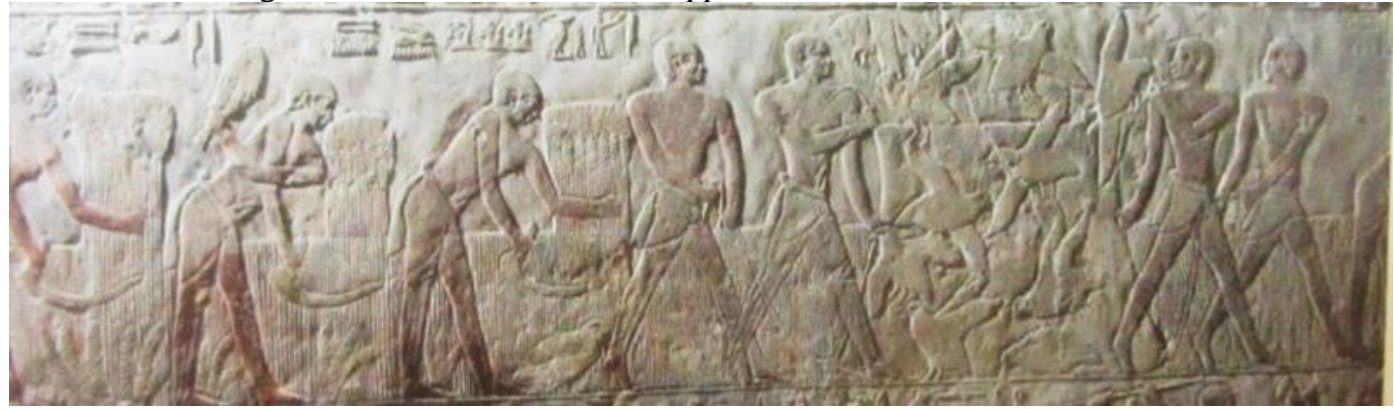

After Kanawati, 2007

A scene from the tomb of Nebamun (Fig. 2) though badly damaged shows four farmers involved in quail trapping in harvest field. They are represented standing among the tall stubble of a newly cut grain field, grasping a delicate meshed net over the field (Houlihan, 1986; Parkinson, 2008).

Fig. 2

The ground net in the New Kingdom tomb of Nebamun at Thebes

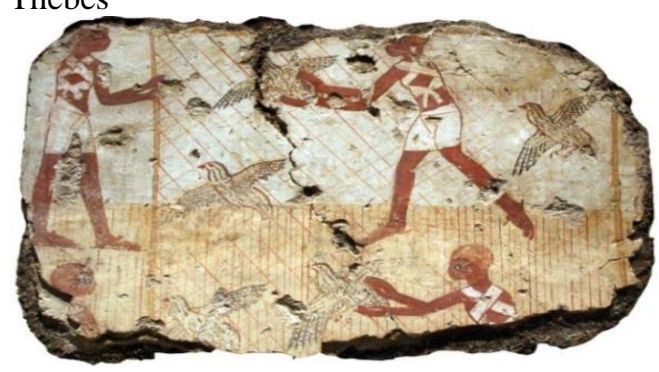

After Parkinson, 2008

4.1.2. The Scarer and the Tree Net in in orchards and Gardens

In Gardiner's sign list (A 59) the figure of the Scarer, a man threatening any creature with what seems to be a stick, appeared as a determinative in the ancient Egyptian verb shr that means drive away, or scare away, or frighten away

59 of man threatening with Det. 'drive away' in 198 shr 'drive away'.
stick

When the fruits ripened in gardens, it was necessary to protect the harvest from the various flocks of songbirds that invaded the orchards and the vines. Scarers armed with linens and yards, sometimes it also seems slingshot, gesturing and screaming no doubt, were responsible for frightening them (Hugonot, 1989; Bailleul-lesuer, 2012) (Fig. 3). 
Fig. 3

A boy Scarer armed with a sling in the garden

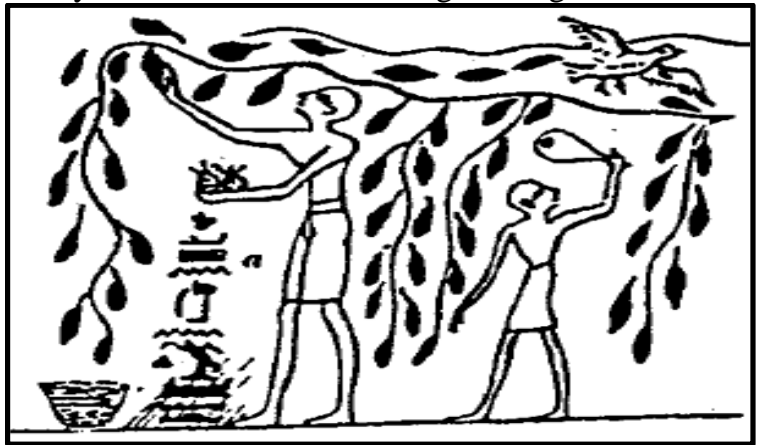

After Hugonot, 1989

particularly during the Old Kingdom period, was associated with a certain type of trapping nets that was used in particular for the aim of scaring birds away from fruit trees. The gardeners used what was called "tree net" that was thrown above the top of the tree and fastened on the ground by means of stakes. ${ }^{2}$ The sides Fig. 4

Old Kingdom scenes of scaring and trapping birds by means of the Scarer and the tree net; a. Tomb of Iymery G 6020 at Giza; b. Tomb of Niankhnesut at Saqqara; c. Tomb of Sekhemkare LG 89 at Giza; d. Tomb of Niankh-khnum and Khnumhotep at Saqqara; e. Tomb of Hetepherakhti at Saqqara; f. Tomb of Neferirtenef at Saqqara.

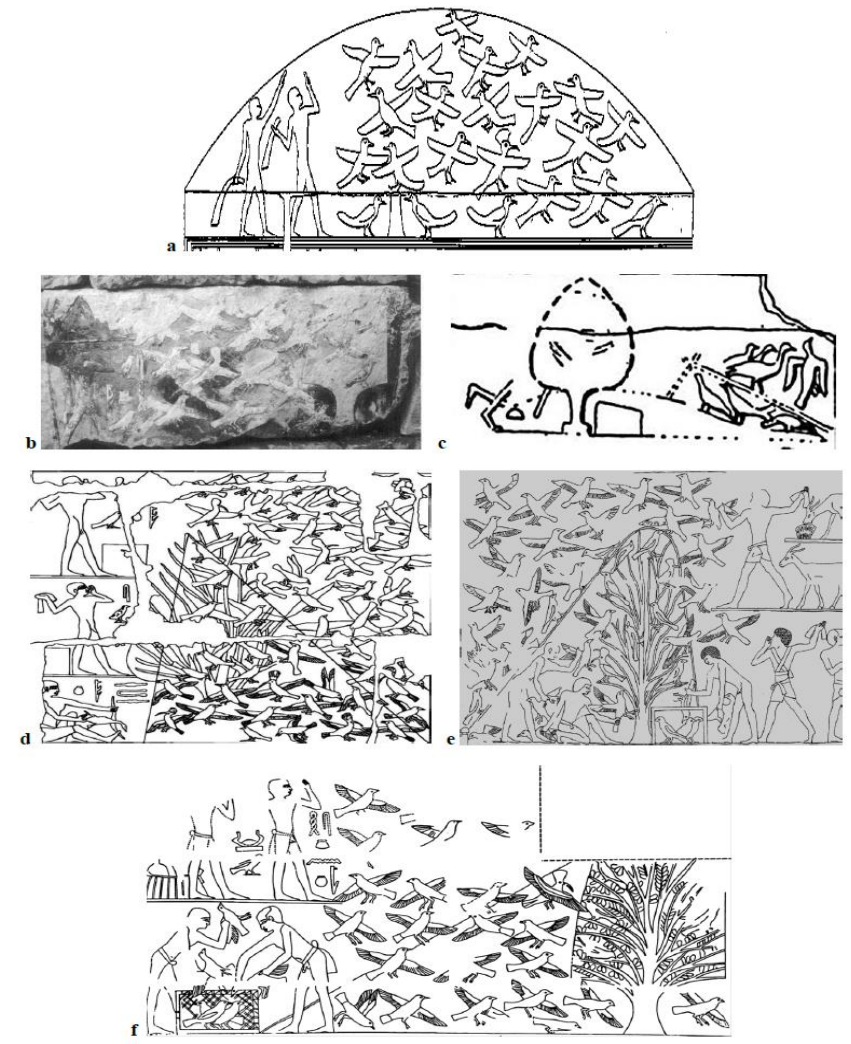

After Lepsius, 1849-1859; Leahy and Mathieson, 2001; Hassan, 1932-1933; Moussa and Altenmüller, 1977; Van de Beek, 2017

2 No scenes were found for this method in both New Kingdom and Late Periods (Slingenberg, 2016; BailleulLeSuer, 2016). of the net were open to allow the birds to settle on the branches of the tree. The gardeners would make mouth noise and hand gestures by waving a piece of cloth or a sling to scare birds away and at the same time draw them to the net trap (Bailleul-LeSuer, 2016) (Fig. 4).

The scene of scaring and trapping birds by means of the Scarer and the tree net is represented in 10 Old Kingdom tombs; two tombs in Giza (the 5th Dynasty tombs of Iymery G 6020 (Weeks, 1994) and Sekhemkare LG 89 (Hassan, 1943)), while the others are located at Saqqara (the $5^{\text {th }}$ Dynasty tombs of Neferirtenef (Van de Walle, 1978), Akhethotep (Ziegler, 1993), Hetepherakhti (Mohr, 1943), Niankhkhnum and Khnumhotep (Moussa and Altenmüller, 1977), and the $6^{\text {th }}$ Dynasty tombs of Ankhmahor (Kanawati and Hassan, 1997), Hesi (Kanawati and Abder-Raziq, 1999), Kagemni (Firth and Gunn, 1926), and Niankhnesut (Leahy and Mathieson, 2001). 
The scenes denote that the task of the Scarer was given to two individuals, usually young boys. They seem to have more fun than any return from work. Generally, children enjoy making noise and running (Sax, 2003). The task of scaring and chasing birds was among the other minor undangerous tasks that were performed by the young peasant sons as helpers or assistants for the older peasants in fields and gardens (El-Kilany and Kamal, 2012).

Though three scenes from the Old Kingdom representing scaring and trapping birds by means of the Scarer and the tree net show that the task of the Scarer was not only assigned to youthful healthy boys but also dwarfs (Fig. 5). The scenes are found in the tombs of Akhethotep, Ankhmahor, and Hesi at Saqqara (Ziegler, 1993; Kanawati and Hassan, 1997; Kanawati and Abder-Raziq, 1999). It is worth mentioning that the two scarers represented in these scenes are not both dwarfs, but only one dwarf accompanied by a young boy.

Fig. 5

The Dwarf Scarer in the Old Kingdom scenes of scaring and trapping birds.

a. The tomb of Akhethotep; $b$. The tomb of Hesi

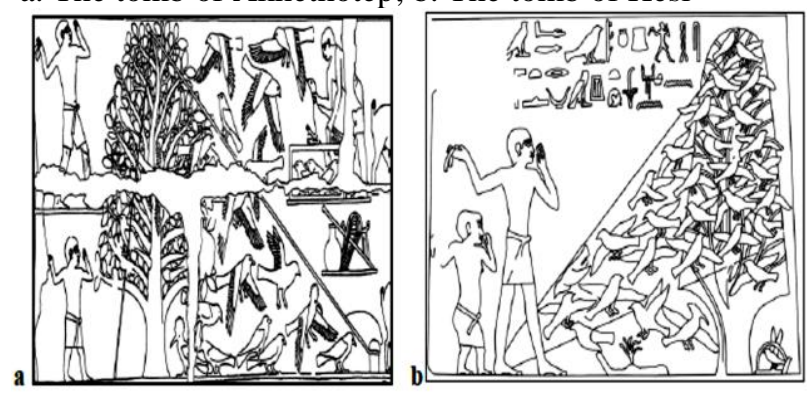

After van de Beek, 2017

The fruit or grain eater birds belong to the species of passerines, perching birds, or songbirds. Various birds of this species were known in ancient Egypt. The golden orioles (Oriolus oriolus gnw) was the most popular species depicted in the Old and Kingdom scenes of trapping the plundering birds in orchards and gardens with tree net. The usual accompanied inscription in such scenes was; sḥwi gnw / $\underline{d} w$ gnw $m \underline{t b}$ "Rounding up orioles and placing them in a crate" (Wassell, 1991; BailleulLeSuer, 2016).

The great fruit eating species of birds that were commonly represented on New Kingdom ostraca from Deir el-Madina were certain species of Corvus crow (Houlihan, 1986) (Fig. 6). It could be the same situation later on for the following periods whether in Egypt or elsewhere in the world.
Probably this was the reason for adding the word "crow" to the verb "scare" in describing the tool for protecting the crops from birds in general.

Fig. 6

A Ramesside ostracon from Deir el-Madina showing the scarer boy standing near a Dum tree while crows feeding on its fruits.

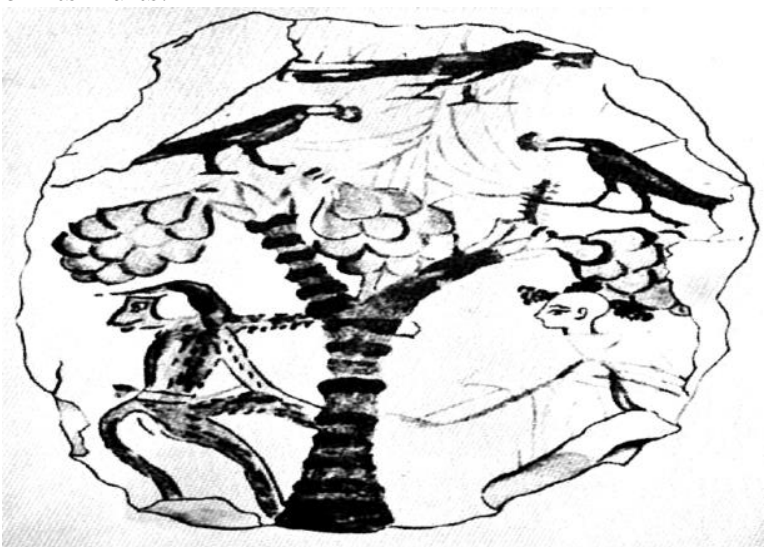

After Houlihan, 1986

The relation between the Scarer and the crow was expressed in a metaphorical and humorous manner in a small theme on a $20^{\text {th }}$ Dynasty "Erotic and Satirical Papyrus" (Fig. 7). The theme switches roles through showing the Scarer and the guardian of a sycamore fig tree in the form of a hippopotamus perched in the tree, while a crow climbs a ladder attached to the top of the tree and tries to pick the figs (Houlihan, 1986; Vandier d'Abbadie, 1964).

\section{Fig. 7}

A theme from a $20^{\text {th }}$ Dynasty "Erotic and Satirical Papyrus" for the scarer and the crow in a metaphorical and humorous manner

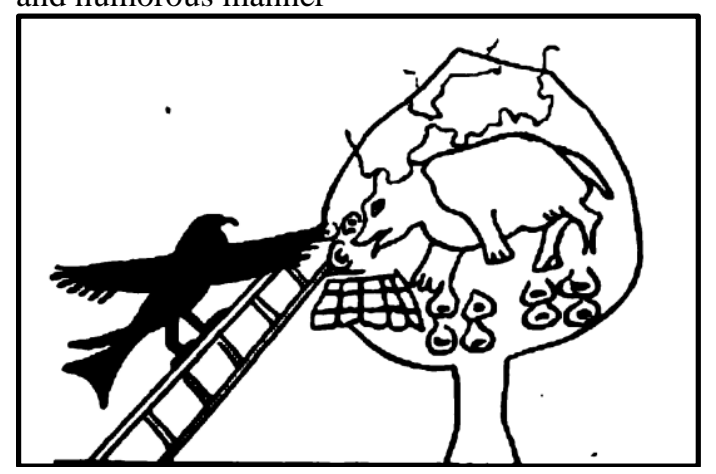

After Vandier d'Abbadie, 1964

There is a unique limestone relief in Brooklyn Museum, 60.197.3, dates back to Amarna Period show a large obscure species of bird with an outspread wing and a long tail perched on a tree (Fig. 8). A group of people is seen gathered near 
the tree. Bailleul-LeSuer and Romano mentioned that this relief is a motif of people scaring away a bird from a tree (Bailleul-LeSuer, 2016; Romano, 2002). The scene could be different from that as suggested from the gestures. The gestures of the individuals here are closer to praying or adoration not frightening like actions of making mouth noise or hand waving. A young man is represented forward seems to be in a kneeling attitude with upraised hands. Behind him is a woman playing tambourine.

Fig. 8

A limestone relief of a bird perched on a tree from Brooklyn Museum.

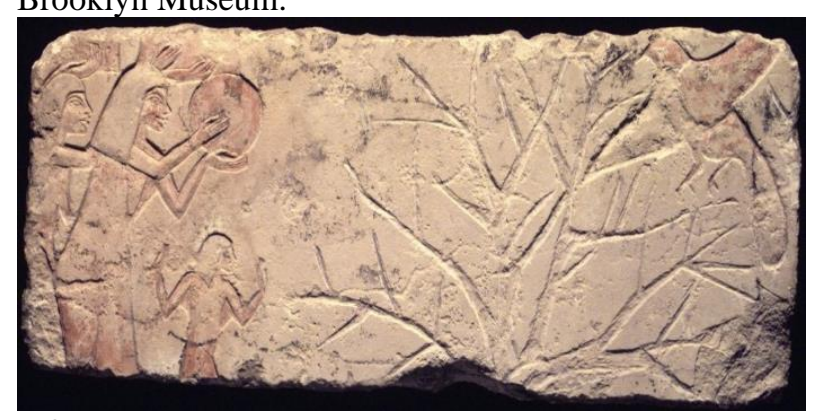

After

https://www.brooklynmuseum.org/opencollection/obje $\underline{\text { cts/78059 (last accessed 16/06/2020) }}$

\subsubsection{The Scarer in Granaries}

After finishing the process of winnowing the corn, men planted their tools in the corn heap, and go to rest after leaving a boy expelling the birds that

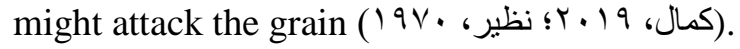

In the ancient Egyptian granaries, it was the task of boys to scare away birds not to attack the granaries, like they did the same for fields and gardens. Thus, they seem to be like real human scarecrows appointed inside the storehouse for threshed grain. There are two examples for this task date back to the New Kingdom period. One is in the Theban private tomb of Pa-hem-neter TT 284, where the scene of the granary occupies the upper registers of the eastern end of the north wall adjacent to the main entrance (Davies, 1939) (Fig. 9).

The granary appears with unroofed enclosure that allowed the entry of birds. The numerous threshed heaps of grain inside the granary were fastened by a low square or circular parapet. Two boys are shown standing in profile between the heaps of

${ }^{3}$ The word corn was used as a general term for any kind of grain, and dolly maybe originated from the word idol. Today, corn dolly is a general term for the art works grain, in a pose imitating that of the modern scarecrow, with outstretching arms and upraised hands as a sign of protection for the grain:

Fig. 9

The granary in the New Kingdom tomb of Pahomneter TT 284

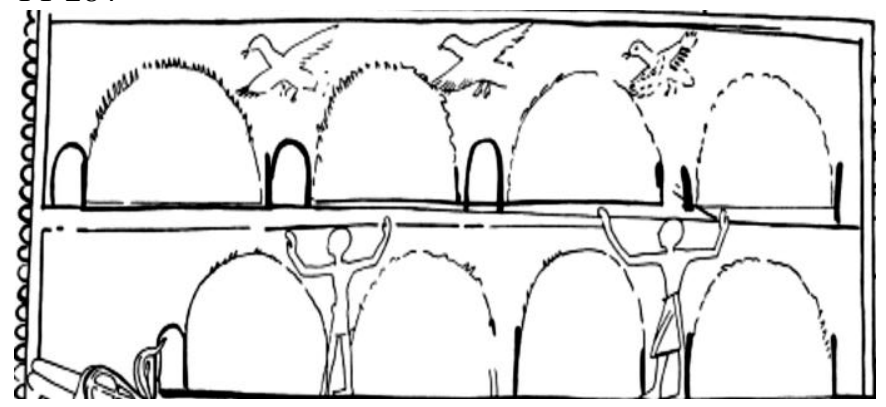

After Davies, 1939

The other example for boy scarer in granary is found in the Theban private tomb of Ipwy TT 217 (Fig. 10). The scene is represented on the north side of the eastern wall of the tomb, where two boys are seen in the roofless granary making mouth noise to scare away the daring plundering birds over the piles of grain. One is represented standing and most probably ready to throw a stone at the birds, while his fellow is seated facing him and slightly turns his head back towards the birds (Davies, 1927).

Fig. 10

The granary in the New Kingdom tomb of Ipwy TT 217

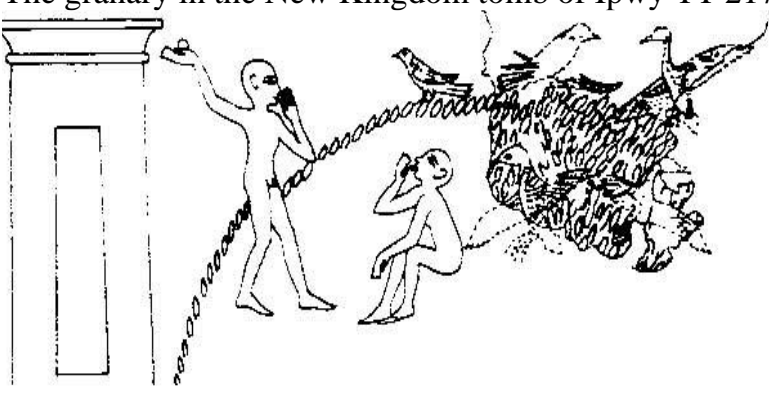

After Davies, 1927

\subsubsection{The Corn Dolly ${ }^{3}$ in the Winnowing Floor}

The use of corn dolly as a scarecrow to scare birds in ancient Egypt was not supported by many references, but only two researchers mentioned that the corn dolly is most probably for a bird or a man in a rude appearance intended as a scarecrow or a god of harvest, or even both in one, and was made of a sheaf of straw or corn stiffened by means of wet clay (Davies, 1917; Wreszanski, 1923;

made of woven straw. In modern Egypt, the corn dolly is popularly known as corn-bride "an object made of ears of corn" (Youngman, 2010; Blackman, 1933). 
Blackman, 1922) (Figure 11a). In real life the straw corn dolly looks like a scarecrow when the leaves of the corn are removed and the head is cut off beneath the first joint, then the straw are sorted into equal length bundles. (Fig. 11b)

\section{Figure. 11a}

The corn dolly in the ancient Egyptian scenes

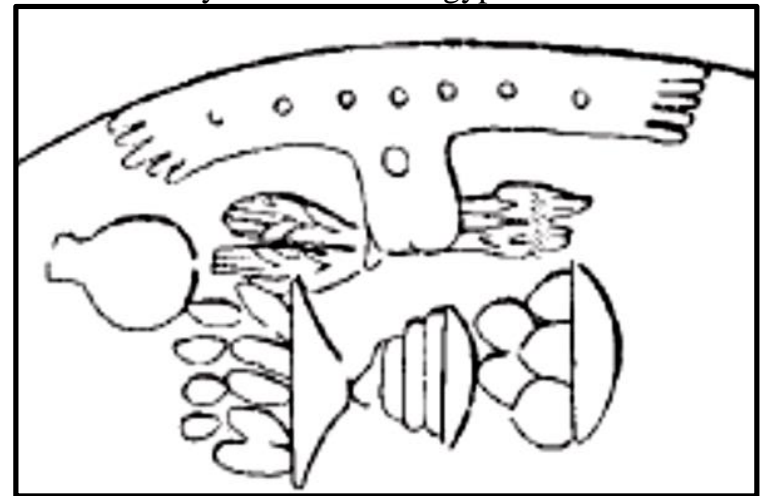

After Sarpaki, 2009

\section{Figure 11b}

The modern straw corn dolly

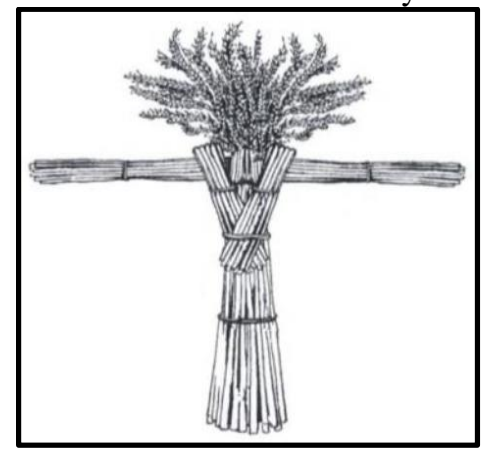

After Franklin and Mason, 2001.

The representation of corn dolly in ancient Egypt dates back to the New Kingdom period. It is found in the theme of winnowing grain included in the harvest scenes on the walls of three private tombs at Thebes; the $18^{\text {th }}$ Dynasty tombs of Nakht TT 52, Djeserkareseneb TT 38, Khaemhat TT 57 (Blackman, 1933) (Table 1). ${ }^{4}$ It was placed on the winnowed heaps of grain and intended to move in the wind in order to scare birds away from the grain in the winnowing floor. ${ }^{5}$

Table 1

Figures of Corn dolly in New Kingdom winnowing themes

\begin{tabular}{|l|l|l|l|}
\hline No. & \multicolumn{1}{|c|}{ Tomb } & Location of the theme \\
\hline $\mathbf{1}$ & $\begin{array}{l}\text { Tomb of Nakht TT } \\
\text { 52 at Sheikh Abd } \\
\text { el-Qurna (Davies, } \\
\text { 1917; Wreszanski, } \\
\text { 1923). }\end{array}$ & $\begin{array}{l}\text { The east wall, on the } \\
\text { right side of the } \\
\text { entrance passageway, } \\
\text { uppermost register } \\
\text { (Hassan, 2017). }\end{array}$ \\
\hline $\mathbf{2}$ & $\begin{array}{l}\text { Djeserkareseneb } \\
\text { TT 38 at Sheikh } \\
\text { Abd el-Qurna } \\
\text { (Wreszanski, } \\
\text { 1923). }\end{array}$ & $\begin{array}{l}\text { The east wall, lower } \\
\text { register to the right } \\
\text { side. }^{6}\end{array}$ \\
\hline
\end{tabular}

${ }^{4}$ It is worth to mention that the owners of the three tombs, where the figure of Corn dolly was represented in the winnowing theme, occupied positions and had titles related to corn cultivation and grain production. Nakht was a scribe, Djeser-ka-re-seneb was in charge of overseeing the measure of crops and harvesting and had the title of the "Grain Counter of Amun", and Khaemhat was formally titled "Overseer of the Granaries of Upper and Lower Egypt" (Brock, 2010).

${ }^{5}$ Winnowing is the process preceding directly the last stage in grain production, which is the grain storage. It was known in the ancient Egyptian reliefs by the term

kha kha mixture of grain and hay from each other by means of a certain tool called scoop (Wb III, 233 (17); Hassan, 2017; Pinch, 1995; Ragueh, 2016). 6

https://www.osirisnet.net/popupImage.php?img=/tomb es/nobles/djeserkareseneb38/photo/djsrkasnb_th_ewall _14_db_ectoplasm.jpg\&lang $=$ en $\&$ sw $=1024 \&$ sh $=600$ (last accessed 28/04/2020). 


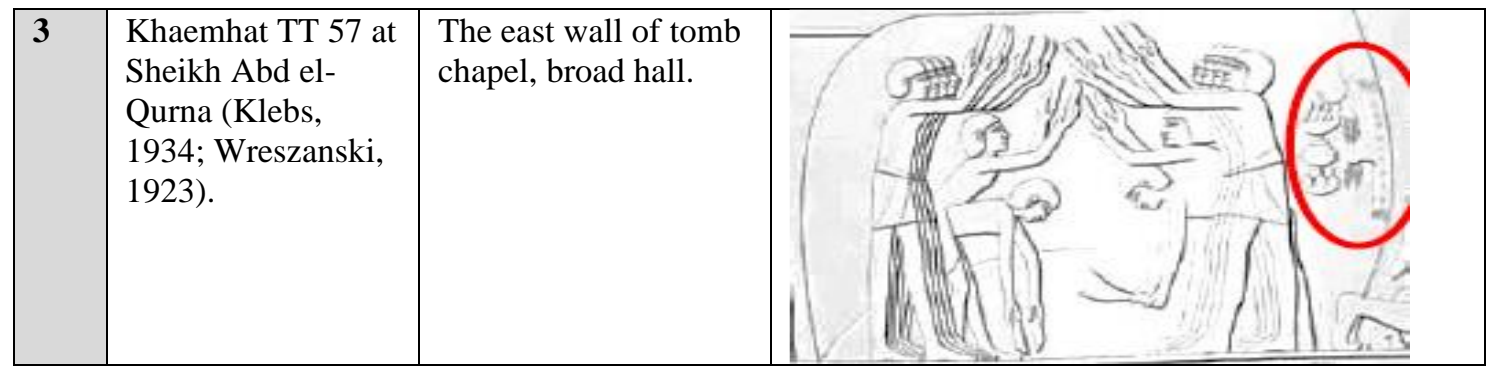

Both of two main elements of the ancient Egyptian form of corn dolly; the bundled sheaf of corn and the crescent are related to Nepri $\stackrel{\square}{\square} 4$ ही the god of grain in ancient Egypt, whose name is written with the determinative "three grains of corn" (Ragueh, 2016). He is generally represented wearing either a sheaf or a crescent on the head. ${ }^{7}$ Concerning the jar and Pieces of bread that appeared beneath the figure of corn dolly in the winnowing themes, they seem to be offerings to have the blessings of Nepri the god of grain. The Concept of Scarecrow in Magical Spells

Most of the magical spells that were used by the farmers in fields and for crop production belonged to the oral tradition, so a few of these spells have survived. There is only one short magical spell, which is related to the protection of the field and the harvest from the plundering flocks of birds (Pinch, 1995): "Spell for preventing a kite from plundering". It describes the way of setting up something like a scarecrow made of a cake attached to the top of a branch. The words of the spell recall god Horus as a sacred falcon to scare away the plundering predatory birds: "A branch of acacia \& ใด šndt; Let it stand up. The man shall then say: O Horus, he has stolen in town and in the field; his thirst is for the birds' field; he shall be cooked and eaten" (Borghouts, 1978; Edmonston, 1986). ${ }^{8}$ The spell denotes that the scarecrow is made of acacia branch in particular to protect the crop from the plundering birds. ${ }^{9}$ The acacia tree played an important role in protection in general as was attested in PT 436 that the acacia was a sacred tree for god Horus, who took it a refuge from lions (Allen, 2015; Sethe, 1908):

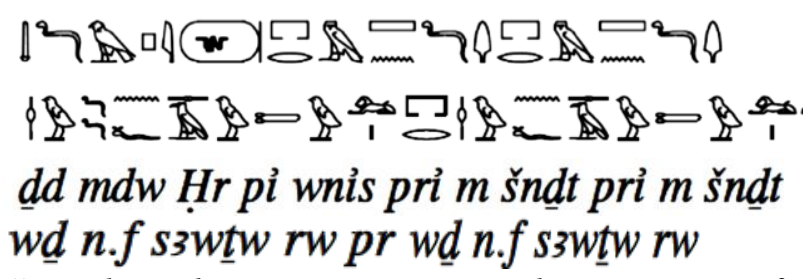

"Words spoken; Unis is Horus, who comes out of the acacia tree, who comes out of the acacia tree, warns of lions, warns of lions".

The scarecrow as a means of scaring birds is considered to be one of the surviving Folkways from ancient Egypt (Hansen, 2008). Its well-known present Arabic names are Khial Almatih and Alfazaea. The modern farmers used dummies (Fig. 12), not life boy scarers as in the ancient Egyptian orchards, gardens, and granaries, in a caricatured human form that formed of straw and worn-out clothing and usually setup on crossed woody poles or branches that were fastened with a rope to assure flexibility (Król, Kao, and Hernik, 2019). Though nothing is documented; the present form of a scarecrow might be inspired by a mixture of the ancient Egyptian means of scaring birds: the human form of the scarecrow normally replaced the real male or boy, while the straw may come from the straw corn dolly. Though the branches employed in making the scarecrow could be

\footnotetext{
${ }^{7}$ Nepri was the son of goddess Renenutet, the goddess of fertility and harvest and the "Lady of Granary". He personifies the annual growth of grains. His birth was celebrated on the first day of the harvest in the month Pakhons that is related to the harvest festival of his mother Renenutet. This is attested in the inscription accompanied a scene for the seated mother serpent-headed goddess Renenutet suckling the child Nepri in a chapel above the harvest scenes in the tomb of Khaemhat (Leibovitch, 1953; Abu-El-Nadar, 2013).

${ }^{8}$ Here the spell recalls the sacred falcon bik in particular, the personification of god Horus, which is originally the Peregrine Falcon, a species of birds of prey feeds mainly on other smaller birds (Wassell, 1991).

${ }^{9}$ The acacia is a thorny tree, which is characterized by a length ranging from 15 to 20 meters, hardness and resistance to bacteria and rot, and high temperature and drought resistance. It also works as windbreaks in open soil. (for more information on the acacia tree and its uses and symbolism in ancient Egypt see:
}

$$
\text { عيسى، سهام و تغريد. (9 } 1 \text { ـ ץ). شجرة }
$$


probably just hangers; they recall to the mind the sacred acacia branch of god Horus. The scarecrow is actually one of the characteristics of the surviving Egyptian rural landscape.

\section{Figure 12}

A modern Egyptian scarecrow in the field

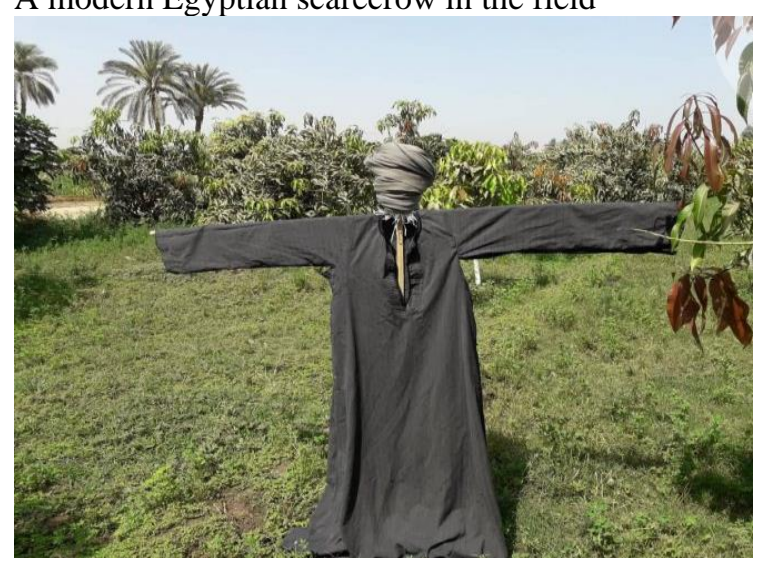

Afterhttps://www.weladelbalad.com/app/uploads/sites/ 9/2019/06/1559485113 500_895513_61354631_4479 74956031736 8357314979950493696_n-800x600.jpg (last accessed 10/06/2020)

\section{Conclusion}

The concept of the scarecrow in the ancient Egyptian fields was only attested in the stages of harvesting and winnowing the corps. This was conducted using several methods (Table 2) that evolved later to represent the modern form of the scarecrow seen until today in the modern Egyptian fields.

Table 2

Methods used as scarecrows in ancient Egypt.

\begin{tabular}{|c|c|c|c|c|}
\hline No. & Tomb & Site & Dynasty & Method \\
\hline 1 & Mereruka & Saqqara & $6^{\mathrm{t}}$ & Bird netting \\
\hline 2 & Nebamun & Thebes & 18 & (the ground or hand net) \\
\hline 3 & Iymery G 6020 & & \multirow{6}{*}{5} & \multirow{12}{*}{ Scarer } \\
\hline 4 & Sekhemkare LG 89 & Giza & & \\
\hline 5 & Neferirtenef & \multirow{8}{*}{ Saqqara } & & \\
\hline 6 & Akhethotep & & & \\
\hline 7 & Hetepherakhti & & & \\
\hline 8 & Niankh-khnum and Khnumhotep & & & \\
\hline 9 & Ankhmahor & & \multirow{4}{*}{6} & \\
\hline 10 & Hesi & & & \\
\hline 11 & Kagemni & & & \\
\hline 12 & Niankhnesut & & & \\
\hline 13 & Pahomneter TT 284 & \multirow{2}{*}{ Thebes } & New Kingdom & \\
\hline 14 & Ipwy TT 217 & & 19 & \\
\hline 15 & Nakht TT 52 & \multirow{3}{*}{ Thebes } & \multirow{3}{*}{18} & \multirow{3}{*}{ Corn dolly } \\
\hline 16 & Djeserkareseneb TT 38 & & & \\
\hline 17 & Khaemhat TT 57 & & & \\
\hline
\end{tabular}

According to the above table the scarecrow methods for scaring birds in ancient Egyptian fields and gardens are mainly three; the bird netting (the ground or hand net), the scarer, and the corn dolly. The earliest one is the ground or hand net that was first attested in the Old Kingdom tomb of Mereruka at Saqqara and was once later represented in the New Kingdom tomb of Nebamun. There is no depiction was found for any one of the three scarecrow methods in the Middle Kingdom period.
The concept of the scarecrow in the ancient Egyptian orchards and gardens appeared in the form of the life boy scarer, the most popular scarecrow method, that is indicated in the ancient Egyptian determinative of a man threatening any creature with a stick or any other scaring device $\mathrm{H}^{\circ}$ The total number of the ancient Egyptian scenes that represent the figure of the scarer, as indicated in Table 2, is 12, all of which date back to the Old 
Kingdom period, except for two scenes that belong to the New Kingdom period.

The figure of the scarer in the Old Kingdom scenes was associated with a particular method for scaring and trapping at the same time the plundering songbirds, of which the most popular species are the golden orioles. This method was the tree net that was only represented in ten Old Kingdom tombs.

The main characteristics of the figure of the scarer as was attested in the Old Kingdom scenes of scaring and trapping birds by the tree net; making mouth noise like shouting and hand gestures like waving a bird-scaring device that was usually a piece of cloth. Another different hand gesture for the scarer appeared in the New Kingdom scenes of granaries that is the outstretching arms as a sign of protection for the piles of grain.

The task of the scarer in ancient Egypt was assigned to two individuals, who were usually young boys. Dwarfs had a share in this but only in three cases from the Old Kingdom period.

The appearance of the New Kingdom corn dolly as the straw doll scarecrow method for scaring birds in ancient Egypt was associated with the stage of winnowing grain that is only attested in three 18th Dynasty Theban private tombs (Table 2). The ancient Egyptian name for winnowing was written

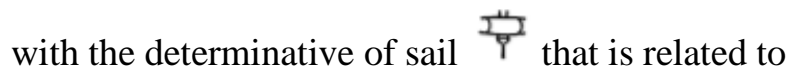
wind, in order to denote the importance of wind for both winnowing and doll scarecrow (the winged crescent shape). It greatly helps in removing straw, hay and dirt, and at the same time the more wind the more movement for wings (of doll scarecrow) and the more scare for the plundering birds.

The wings of the doll scarecrow in the New Kingdom winnowing scenes appear spreading in an enveloped attitude to guard and protect the area beneath it. This attitude and its functional indication are similar to that of the life boy scarecrow or scarer in the granaries with the outstretching arms.

The scarecrow in its present form was not known in ancient Egypt, but the concept was known to frighten birds was early acknowledged as a need and necessity for an agricultural community that preserves the crop from bird attacks.

\section{References}

Abu-El-Nadar, W. (2013). God Nepri in Ancient Egyptian Religion. Egyptian Journal of
Archaeological and Restoration Studies, 3(2). 107114

Allen, J. (2015). the Ancient Egyptian Pyramid Texts, London.

Bailleul-lesuer, R. (2012). The Practical Role of Birds in Ancient Egypt. In Between Heaven and Earth Birds in Ancient Egypt, the Oriental Institute of the University of Chicago, 23-32

Bailleul-lesuer, R. (2016). The Exploitation of Live Avian Resources in Pharaonic Egypt: a SocioEconomic Study, Doctoral thesis, Department of Near Eastern Languages and Civilizations, the Faculty of the Division of the Humanities, University of Chicago.

Blackman, W. (1922). Some Occurrences of the Corn'aruseh in Ancient Egyptian Tomb Paintings. Journal of Egyptian Archaeology, 8(3/4), 31-32.

Blackman, W. (1933). Some Further Notes on a Harvesting Scenes. Journal of Egyptian Archaeology, 19(1/2), 31-32.

Borghouts, J. (1978). Ancient Egyptian Magical Texts, Religious Texts Translation Series NISABA, Volume 9, Brill, Leiden.

Brock, J. (2010). Five Surveyors of the Gods: XVIII Dynasty of New Kingdom Egypt - New Kingdom c. 1400 B.C., Sydney, Australia.

Davies, N. and N. de G. (1939). Harvest Rites in a Theban Tomb. Journal of Egyptian Archaeology, 25(2), 154-156

Davies, N. de G. (1917). The Tomb of Nakht at Thebes, New York

Davies, N. de G. (1927). Two Ramesside Tombs at Thebes, the Metropolitan Museum of Art, New York.

Edmonston, W. (1986). The Induction of Hypnosis, John Wiley \& Sons, New York.

El-Kilany, E. and Kamal, S. (2012). The Role and Depiction of Peasant Children in Ancient Egypt (Old and New Kingdoms, a comparative study). Egyptian Journal of Tourism Studies, 11(1), 12-25.

Firth, C. and Gunn, B. (1926). Teti Pyramid Cemeteries, Volume II, Service des Antiquités de l'Égypte, Excavations at Saqqara, Institut Français d'Archéologie Orientale, Cairo.

Franklin, A. and Mason, P. (2001). Lammas: Celebrating Fruits of the First Harvest, Llewellyn Worldwide, U.S.A.

Hansen, N. (2008). Omm Sety's Living Egypt Surviving Folkways from Pharaonic Times, Glyphdoctors, Chicago.

Hassan, G. (2017). Mechanical Engineering in Ancient Egypt, Part 53: Farming Tools. International Journal of Engineering and Techniques, 3, (4), 120.

Hassan, S. (1943). Excavations at Giza 1932-1933, Volume 4, Service des Antiquités de l'Égypte, Cairo. 
Houlihan, P. (1986). the Birds of Ancient Egypt, the American University in Cairo Press, Egypt.

Hugonot, J. (1989). Le jardin dans l'Egypte ancienne, Frankfort am Main.

Kanawati, N. (2007). Mereruka and King Teti the Power behind the Throne, Supreme Council of Antiquities, Egypt.

Kanawati, N. and Abder-Raziq, M. (1999). The Tomb of Hesi, the Teti Pyramid Cemetery at Saqqara, Volume V, the Australian Centre for Egyptology, Warminster, Wiltshire.

Kanawati, N. and Hassan, A. (1997). The Tomb of Ankhmahor, the Teti Pyramid Cemetery at Saqqara, Volume II, the Australian Centre for Egyptology, Warminster, Wiltshire.

Kimball, J. (2016). Scarecrows have long history, https://www.concordmonitor.com/All-aboutscarecrows-4927005.

Klebs, L. (1934). Die Reliefs und Malereien des Neuen Reiches III, Heidelberg.

Król, K., Kao, R., and Hernik, J. (2019). The Scarecrow as an Indicator of Changes in the Cultural Heritage of Rural Poland. Sustainability 11, 1-24

Leahy, A. and Mathieson, I. (2001). The Tomb of Nyankhnesut (Re)discovered. Journal of Egyptian Archaeology, 87, 33-42.

Leibovitch, J. (1953). Gods of Agriculture and Welfare in Ancient Egypt. Journal of Near Eastern Studies, 12, (2), 73-113.

Lepsius, C. (1849-1859). Denkmäler aus Ägypten und Äthiopien, Zweite Abtheilung, Denkmäler des Alten Reiches, II, Berlin.

Mohr, H. (1943). The Mastaba of Hetep-her-akhti, Study on an Egyptian Tomb Chapel in the Museum of Antiquities, Leiden.

Moussa, A. and Altenmüller, H. (1977). Das Grab des Nianchchnum und Chnumhotep, Old Kingdom Tombs at the Causeway of King Unas at Saqqara, Mainz am Rhein.

Parkinson, R. (2008). The Painted Tomb-Chapel of Nebamun: Masterpieces of Ancient Egyptian Art in the British Museum, British Museum Press, London.

Pinch, G. (1995). Magic in Ancient Egypt, University of Texas Press.

Ragueh, Ch. (2016). The blessing of grain represented in god 'Nepri' and his affiliate gods of grain: 'Osiris' and 'Renenutet, Journal of the Association of Arab Universities for Tourism and Hospitality, 13(2-1), 1-22.

Romano, J. (2002). In the Fullness of Time Masterpieces of Egyptian Art from American Collections, University of Washington Press, Seattle \& London.

Sarpaki, A. (2009). Harvest Rites and Corn Dollies in the Bronze Age Aegean. Hesperia Supplements, 42, Essays on Ritual and Cult in Crete in Honor of Geraldine C. Gesell, 59-67

Sax, B. (2003). Crow, Reaktion Books, London.

Sethe, K. (1908). Die Altaegyptischen Pyramidentexte Pyramidentexte nach den Papierabdrucken und Photographien des Berliner Museums, J. C. Hinrichs'sche Buchhandlung, Leipzig.

Slingenberg, M. (2016). Catch me if you can’; Bird Trapping with a Hexagonal Net in the 'Daily Life' Scenes in the Old Kingdom Elite Tombs of the Memphite Area, Master thesis Classics and Ancient Civilizations, track Egyptology, Volume I, Faculty of Humanities, Leiden University.

Van de Beek, N. (2017). To kill a songbird: Scenes of catching songbirds in Old Kingdom elite tombs. Saqqara Newsletter, (15), 55-67

Van de Walle, B. (1978). La Chapelle Funéraire de Nefererirtenef, Musées Royaux d'Art et d'Histoire, Brussels.

Vandier d'Abbadie, J. (1964). Catalogue des ostraca figures de Deir el Médineh, Institut Français d'Archeologie Orientale, Le Caire.

Wassell, B. (1991). Ancient Egyptian fauna: a lexicographical study, Doctoral thesis, Volume I, School of oriental Studies, Durham University.

Weeks, K. (1994). Mastabas of Cemetery G 6000. Including G 6010 (Neferbauptah); G 6020 (Iymery); G 6030 (Ity); G 6040 (Shepseskafankh), Giza Mastabas, Volume 5, Department of Ancient Egyptian, Nubian, and Near Eastern Art, Museum of Fine Arts, Boston.

Wreszanski, W. (1923). Atlas zur altaegyptischen Kulturgeschichte, I, Leipzig.

Youngman, A. (2010). "Celebrating harvest festivals", 5 to 7 Educator 2010.69. 9-10

Ziegler, C. (1993). Le Mastaba d'Akhethetep Une Chapelle Funéraire de l'Ancien Empire, Départment des Antiquités Égyptiennes du Musée du Louvre, Paris 